\title{
Territory Size in Mixed-grass Prairie Songbirds
}

\author{
STEPHANIE L. JONES ${ }^{1,2}$ \\ ${ }^{1}$ U.S. Fish and Wildlife Service, P. O. Box 25486 DFC, Denver, Colorado 80225 USA \\ ${ }^{2}$ Corresponding author. E-mail: Stephanie_Jones@fws.gov
}

Jones, Stephanie L. 2011. Territory size in mixed-grass prairie songbirds. Canadian Field-Naturalist 125(1): 12-15.

I estimated breeding territory size in mixed-grass prairie songbirds, and explored how it varied among bird species, time-ofseason, and year. The study was conducted at Bowdoin National Wildlife Refuge in north-central Montana during 2007-2009. Across all species, months and years, mean breeding territory size was estimated at 0.43 ha $(\mathrm{SE}=0.03, n=129)$. Estimates were nearly identical across study species: Sprague's Pipits (Anthus spragueii), Grasshopper (Ammodramus savannarum), and Baird's (A. bairdii) sparrows. There was no significant variation in territory size across months, suggesting little to no dependence on nest phase. In contrast, I found significant variation in territory size among years $(P=0.034)$, that did not interact meaningfully with species $\left(R^{2}=0.02, P=0.603\right)$. This suggests that factors that vary annually appear to be affecting all bird species in a similar manner, which could be related to differences in vegetation structure and/or site quality (perhaps as a function of weather) or less likely, variation in population density.

Key Words: Baird's Sparrow, Ammodramus bairdii, Grasshopper Sparrow, Ammodramus savannarum, Sprague's Pipit. Anthus spragueii, flush mapping, grassland birds, territory mapping.

Territoriality is a common behavioral pattern exhibited by animals in which a portion of the home range is defended. In birds, territories are often defended using agonistic visual and/or auditory displays that may employ flight, posture, plumage (color and pattern), and song (Nice 1941; Whitaker and Warkentin 2010). Many types of territories have been defined, depending on function and time-of-year, ranging from those of the individual to the colony. Nice (1941) defined a "Type A" breeding territory as an exclusive area in which a bird pair may complete its breeding cycle free from conspecific hindrance. Type A territories function in assisting with pair formation, nest success, ensuring paternity, protecting food resources (particularly for young), and reducing disease (Nice 1941; Lack 1966; Whitaker and Warkentin 2010).

Knowledge of territory size is useful for gauging area requirements necessary setting management and conservation goals for populations of interest (Wiens et al. 1985). Such information is also of value in assessing and comparing site quality and habitat within and between geographic areas (Wiens et al. 1985; Whitaker and Warkentin 2010). Unfortunately, data on territory size for many mixed-grass prairie songbirds is sparse (Vickery 1996; Robbins and Dale 1999; Green et al. 2002). In this paper I present estimates of Type A breeding territory size and how it varied among songbird species, year, and time-of-season. Three northern mixed-grass prairie species that defend Type A breeding territories were chosen for study: Sprague's Pipits (Anthus spragueii), Grasshopper Sparrow (Ammodramus savannarum), and Baird's Sparrow (A. bairdii).

\section{Study Area}

Our study was conducted over three years during 2007-2009 at Bowdoin National Wildlife Refuge (NWR) in Phillips County, near the town of Malta in north-central Montana ( $48^{\circ} 24^{\prime} \mathrm{N}, 107^{\circ} 39^{\prime} \mathrm{W}$; ca. $750 \mathrm{~m}$ above mean sea-level). The study area consisted of mostly flat to gently rolling native mixed-grass prairie. The climate was continental and semiarid, characterized by strong winds and high evaporation rates. The plant community was dominated by western wheatgrass (Pascopyrum smithii), needle-and-thread (Stipa comata), blue grama (Bouteloua gracilis), and spike moss (Selaginella densa). Low shrubs (Sarcobatus vermiculatus, Artemisia cana, Ceratoides lanata) were widespread but sparse and trees largely absent.

\section{Methods \\ Territory mapping}

I measured territory size using two methods, depending on bird species. For Grasshopper and Baird's sparrows, I used the flush-mapping technique (Wiens 1969), a technique specifically designed for secretive grassland birds that display from the ground or low perches. This method is thought to give practical estimates of territory size, at least for that day and time-of-season (Reed 1985). In this study, I opportunistically located a singing male that was then approached and flushed, with its initial position, flight path, and landing position recorded using Global Positioning System (GPS). This procedure was repeated until a minimum of 10 consecutive flushes were mapped; the individual was not visited again that year.

Sprague's Pipits required a different technique since they extensively display by singing from the air throughout the breeding period (Robbins 1998). Here, positions were estimated by standing directly beneath the singing male, marking the approximate ground position using GPS. Again, a minimum of 10 positions were obtained for each territory, with special attention to delineating the outer area of display. 
For all species, mapping was conducted throughout daylight hours, using territorial behavior, primarily singing and countersinging displays, as well as agonistic behaviors, particularly chasing. When the individual male being mapped went out of sight and sound, song playback was then used to call the individual back into the central territory area until 10 unique positions were recorded. Positions for all techniques were marked using a ${ }^{\circledR}$ Garmin GPSmap76CSx, which provided an optimal accuracy of $\pm 5 \mathrm{~m}$.

\section{Analysis}

Universal Transverse Mercator (UTM) coordinates were recorded for each position. Territory positions were mapped, and total area and periphery were calculated using ArcInfo GIS software (Environmental Systems Research Institute $\left.2007^{*}\right)$, using minimum convex polygons with Hawth's tool extension in ArcMap (Environmental Systems Research Institute $\left.2007^{*}\right)$.

Statistical analyses were conducted using SPSS v. 17.0 (SPSS 2008). Territory estimates were summarized by bird species, (Sprague's Pipit, Grasshopper and Baird's sparrows), month (June vs. July) and year (2007, 2008 and 2009). Effects and their interaction were tested using univariate analysis of variance, treating each factor as fixed. Simple differences in means and proportional reduction in error terms $\left(R^{2}\right)$ were employed as measures of strength. Individual territories were treated as independent sample units, within and among months and years; species, month and year were treated as between-subject factors. Post hoc comparisons were conducted using the Bonferroni test (SPSS 2008). Significance level for all statistical tests was set at an $\alpha$-level of 0.10 .

\section{Results}

Across all species, months and years, mean Type A territory size was estimated at 0.43 ha $(\mathrm{SE}=0.03$, $n=129$; Table 1). Values ranged from a low of 0.10 ha (Baird's Sparrow) to a high of 2.10 ha (Sprague's Pipit). Across all years, mean territory size varied little among bird species (Mean range $=0.03$ ha, $P=0.879$ ). There was even less variation between June and July, suggesting little, if any, dependence on nest phase $\left(\right.$ mean $_{\text {diff }}=0.01$ ha, $\left.P=0.867\right)$. In contrast, there was variation in territory size among years $(P=0.034)$, that did not interact with species $\left(R^{2}=0.02, P=0.603\right.$; Figure 1). Mean territory size in 2008 (mean $=0.54$ ha, $n=28)$ was significantly greater $(P=0.030)$ than in 2007 (0.35 ha, $n=54$; Table 1$)$.

\section{Discussion}

Territorial behavior may serve to partition available habitat and resources, although this relationship can vary with species, season, year, and with other factors (Fratwell and Lucas 1970). Territorial behavior also serves to space out the birds and minimize (but not prevent) direct competition for food, particularly where

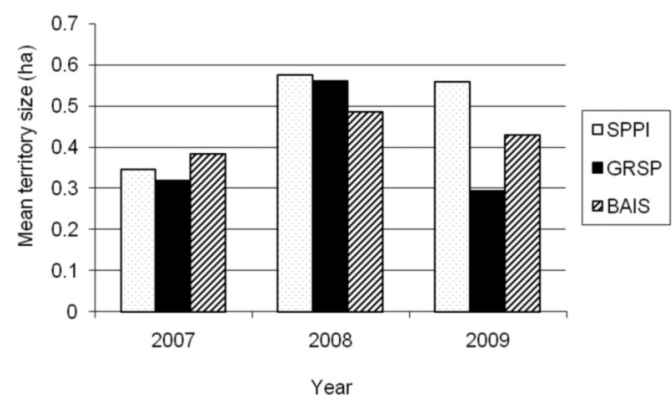

FIgURE 1. Annual variation in Type A breeding territory (Nice 1941) sizes for three grassland species: SPPI $=$ Sprague's Pipit, GRSP $=$ Grasshopper Sparrow, and BAIS = Baird's Sparrow during June and July of 2007-2009 in north-central Montana. Withinyear estimates were similar across species most years.

foraging time and space and food availability are reduced (Tryon and MacLean 1980). Birds may not be trying to maximize the number of individuals in an area, but occupying, or attempting to occupy, areas that maximize their reproductive fitness (Fratwell and Lucas 1970).

In this study, territory size estimates were all remarkably similar among species, but not across years. Given the standardized methodology used here, these two findings suggest that the natural factors that determine territory size vary annually and appear to be affecting these three grassland bird species in a similar manner. This could be related to differences in vegetation structure and/or site quality (perhaps as a function of weather) or less likely, variation in population density. Although somewhat taxonomically distinct, the species studied here occupy generally similar ecological niches with regards to foraging substrates, as well as nest-site characteristics and breeding phenology (Dieni and Jones 2003; Jones et al. 2010). Clearly these annual factors could have been causing the notable increase in mean territory size between 2007 and 2008 documented here.

Conversely, I found that mean territory size did not vary with time-of-season. Territory measurements were taken well after the spring arrival of each species (Jones et al. 2010), eliminating the effect of increasing population pressure on territory size due to more arrivals. All three of these species were found to have single frequency peaks in clutch initiation dates during 1997-2007, suggesting a tendency here towards single broods per season (Jones et al. 2010). Therefore, territories defended in July should primarily represent the later stages of breeding and this is what would be expected in Type A territorial defense.

Territory size estimates for the species studied here are generally smaller than that reported in the literature, although relatively few studies have been conducted for either Sprague's Pipits (Robbins and Dale 1999) or 
TABLE 1. Territory size statistics for three species of mixed-grass prairie songbirds at Bowdoin National Wildlife Refuge, Montana. Mean territory size did not vary significantly with species or month, but did vary $(P=0.034)$ between 2007 and 2008 .

\begin{tabular}{llllcl}
\hline \hline Factor & Mean ha (SE) & SD & Minimum & Maximum & $n$ \\
\hline $\begin{array}{l}\text { Species } \\
\quad \text { Sprague's Pipit }\end{array}$ & $0.45(0.05)$ & 0.35 & 0.15 & 2.10 & 41 \\
$\quad \begin{array}{l}\text { Grasshopper Sparrow } \\
\quad 0.43(0.07)\end{array}$ & 0.36 & 0.16 & 1.87 & 26 \\
$\quad$ Baird's Sparrow & $0.42(0.03)$ & 0.24 & 0.10 & 1.18 & 62 \\
Month & & & & & \\
$\quad$ June & $0.41(0.03)$ & 0.22 & 0.10 & 1.13 & 41 \\
$\quad$ July & $0.40(0.04)$ & 0.31 & 0.11 & 2.10 & 60 \\
$\quad$ Year & & & & \\
$\quad$ 2007 & $0.35(0.03)$ & 0.19 & 0.10 & 1.13 & 54 \\
2008 & $0.54(0.07)$ & 0.37 & 0.19 & 1.87 & 28 \\
2009 & $0.46(0.05)$ & 0.34 & 0.11 & 2.10 & 47 \\
\hline \hline
\end{tabular}

Baird's Sparrows (Green et al. 2002). Davis and Fisher (2009) reported a mean territory size of 2.5 ha $(\mathrm{SD}=0.5$, $n=30$ ) for breeding Sprague's Pipits in Saskatchewan, which exceeds my estimate for this species. Measurement error might explain at least some of the difference but details are unavailable (Davis and Fisher 2009). Robbins (1998) measured dimensions of Sprague's Pipits flight display area, and found that singing displays were limited to a relatively small area $(61 \mathrm{~m} \times 55 \mathrm{~m}, n=3)$, calculated here roughly to be a mean area $=0.33$ ha, which was similar to my estimates, particularly in 2007.

Territory sizes in Grasshopper Sparrows varied across their geographic range, from 0.81 ha (Pennsylvania; $n=22$ ) to 1.38 ha (Michigan; $n=6$ ) (Vickery 1996). Smaller average territories were reported from 0.19 ha (w. Pennsylvania; $n=20$ ) to 0.32 ha (W. Virginia) (Vickery 1996). In a grassland study in Wisconsin, Wiens (1969) reported an average territory size of 0.85 ha (range $=0.32-1.74$ ha; $n=73$ ). Territories from Bowdoin NWR were small, averaging 0.43 ha (range: $0.16-1.87$ ha; $n=26$ ), although they were generally within the territory sizes reported for Grasshopper Sparrows. Territory size in Wisconsin (Wiens 1969) changed during the year, decreasing as the breeding season progressed, which was not observed in this study.

In Baird's Sparrow, at Lostwood NWR, North Dakota, territories on plots burned 2 or 4 times between the late 1970s and 1993 ranged from $0.80-2.25$ ha $(n=30$; Winter 1999). This range is larger than in this study, even for 2008 (0.21-0.85 ha). Breeding territory sizes were larger early in the breeding season in North Dakota (Green et al. 2002), which was not the case in this study.

Since the effort here was standardized, temporal comparisons within-species seem valid. However, comparisons between bird species may be suspect in absolute terms. Although flush-mapping method likely gave fairly accurate results for territory size of the two sparrow species studied here, the passive mapping method employed here for Sprague's Pipit likely underestimated territory size for this species. While measurement errors could account for the observed differences, territory sizes can vary with population density, within individuals, and with nesting phenology. Territory sizes also vary at different portions of the species ranges, within different micro-habitats and with habitat quality (DeGraaf 1989).

Type A territoriality is widely prevalent among bird species; it often has regulation implications that are critical for the conservation of populations and are important in the evolution of interspecific interactions (Rappole et al. 1977). Anich et al. (2009) used radiotelemetry to conclude that mapping accurate locations of singing birds provided reasonable estimates of the primary (Type A) use area, which I measured here, but did not provide accurate estimates of the home range. However, the dynamic, fluctuating nature of bird territoriality can complicate the interpretation of mapping data, and that may make comparisons between studies challenging.

\section{Acknowledgements}

This project was funded by the U.S. Fish and Wildlife Service, Nongame Migratory Bird Coordinator, Region 6. Reference to any specific commercial product, process, or service by trade name, trademark, or manufacturer does not constitute or imply its endorsement, recommendation, or favoring by the U.S. Government or any agency. Special thanks go to M. J. Artmann, who analyzed and mapped the territory data using GIS/ARCINFO. J. S. Dieni and MacDougall Jones assisted with the analysis and offered many comments and insights that greatly improved this manuscript. S. K. Davis, A. J. Erskine and an anonymous reviewer provided helpful comments on an earlier version of this manuscript. The findings and conclusions in this article are those of the author and do not necessarily represent the views of the U.S. Fish and Wildlife Service. 
Document Cited (marked $*$ in text)

Environmental Systems Research Institute. 2007. ArcInfo and ArcMap GIS software. Redlands, California. <http:// www.esri.com/> (17 September 2007).

\section{Literature Cited}

Anich, N. M., T. J. Benson, and J. C. Bednarz. 2009. Estimating territory and home-range sizes: do singing locations alone provide an accurate estimate of space use? Auk 126: 626-634.

Davis, S. K., and R. J. Fisher. 2009. Post-fledging movements of Sprague's Pipits. Wilson Journal of Ornithology 121: 198-202.

Dieni, J. S., and S. L. Jones. 2003. Grassland songbird nest site selection patterns in north-central Montana. Wilson Bulletin 115: 388-396.

DeGraaf, R. M. 1989. Territory sizes of Song Sparrows, Melospiza melodia, in rural and suburban habitats. Canadian Field-Naturalist 103: 43-47.

Fratwell, S. D., and H. L. Lucas. 1970. On territorial behavior and other factors influencing habitat distribution in birds: theoretical development. Acta Biotheoreteca 19: $16-36$.

Green, M. T., P. E. Lowther, S. L. Jones, S. K. Davis, and B. C. Dale. 2002. Baird's Sparrow (Ammodramus bairdii). In: The birds of North America, number 638. Edited by A. Poole and F. Gill. Academy of Natural Sciences, Philadelphia, Pennsylvania; American Ornithologists' Union, Washington, D.C.

Jones, S. L., J. S. Dieni, and P. J. Gouse. 2010. Reproductive biology of a grassland songbird community in northcentral Montana. Wilson Journal of Ornithology 122: 455464.

Lack, D. 1966. Population studies in birds. Clarendon Press, Oxford, U.K.

Nice, M. M. 1941. The role of territory in bird life. American Midland Naturalist 26: 441-487.
Rappole, J. H., D. W. Warner, and M. Ramos. 1977. Territoriality and population structure in a small passerine community. American Midland Naturalist 97: 110-119.

Reed, J. M. 1985. A comparison of the "flush" and spot-map methods for estimating the size of Vesper Sparrow territories. Journal of Field Ornithology 56: 131-137.

Robbins, M. B. 1998. Display behavior of male Sprague's Pipits. Wilson Bulletin 110: 435-438.

Robbins, M. B., and B. C. Dale. 1999. Sprague's Pipit (Anthus spragueii). In: The birds of North America, number 439. Edited by A. Poole and F. Gill, Academy of Natural Sciences, Philadelphia, Pennsylvania; American Ornithologists' Union, Washington, D.C.

SPSS. 2008. SPSS v. 17.0 for Windows. SPSS, Inc., Chicago, Illinois, USA.

Tryon, P. R., and S. F. MacLean. 1980. Use of space by Lapland Longspurs breeding in arctic Alaska. Auk 97: 509520.

Vickery, P. D. 1996. Grasshopper Sparrow (Ammodramus savannarum). In: The birds of North America, number 239. Edited by A. Poole and F. Gill, Academy of Natural Sciences, Philadelphia, Pennsylvania; American Ornithologists' Union, Washington, D.C.

Wiens, J. A. 1969. An approach to the study of ecological relationships among grassland birds. Ornithological Monographs 8: 1-93.

Wiens, J. A., J. T. Rotenberry, and B. Van Horne. 1985. Territory size variations in shrubsteppe birds. Auk 102: 500-505.

Winter, M. 1999. Relationship of fire history to territory size, breeding density, and habitat of Baird's Sparrow in North Dakota. Studies in Avian Biology 19: 171-177.

Whitaker, D. M., and I. C. Warkentin. 2010. Spatial ecology of migratory passerines on temperate and boreal forest breeding grounds. Auk 127: 471-484.

Received 8 June 2010

Accepted 28 December 2010 